\title{
Differentiation of malignant from normal and react
mesothelial cells by the argyrophil technique for nucleolar organiser region associated proteins
}

\author{
JON G AYRES, JOHN G CROCKER, NICHOLAS Q SKILBECK \\ From the Departments of Respiratory Medicine and Histopathology, East Birmingham Hospital, Birmingham
}

ABSTRACT Nucleolar organiser regions represent nucleolar activity in both normal and malignante ABSTRACT Nucleolar organiser regions represent nucleolar activity in both normal and malignanto cells. More numerous nucleolar organiser regions have been found in cells from many forms of malignancy than in normal cells. An argyrophilic method of staining these regions (the AgNORo technique) has been applied to specimens of pleura obtained by biopsy or at necropsy in an attempt to differentiate between normal, "reactive," and malignant pleural disease. The number of nucleolars organiser regions in samples taken from 10 patients with normal pleura (mean 1.04 (95\% confidence interval $0.96-1 \cdot 12)$ ) was less than the number seen in samples from 10 patients with "reactive" (inflammatory) pleural disease $(1.75(1.34-2 \cdot 16) ; p<0.001)$. This is the first demonstration of increased numbers of nucleolar organiser regions in an inflammatory condition. In specimens from $25^{\circ}$ patients with mesothelioma the corresponding numbers of nucleolar organiser regions were:s tubulopapillary $(n=10) 5.43(4.42-6.44)$; undifferentiated $(n=5) 5.00(3.29-6.71)$; sarcomatous $(n=5)$ 7.52 (3.96-11.08); and mixed histological types $(n=5) 4.94(3 \cdot 2-6 \cdot 68)$. All these values differo significantly from those for both normal and "reactive" tissue $(p<0.001)$. It is concluded that the AgNOR technique separates "reactive" pleural disease from mesothelioma with a high degree of confidence and is an important advance in the diagnosis of malignant mesothelioma.

Nucleolar organiser regions represent areas of ribosomal DNA on certain chromosomes from which ribosomal RNA is formed' and their numbers per nucleus are thought to reflect nucleolar activity. ${ }^{2}$ Studies of various forms of malignancy ${ }^{3}$ (prostatic carcinoma, ${ }^{2}$ melanocarcinoma, ${ }^{4}$ small cell bronchogenic carcinoma, ${ }^{5}$ and carcinoma of the breast ${ }^{6}$ ) have confirmed that enumeration of nucleolar organiser regions as identified by an argyrophilic method (the AgNOR technique) permits clear differentiation of malignant from benign tissue. This technique stains proteins associated with nucleolar organiser regions. ${ }^{\text {? }}$ In non-Hodgkin's lymphoma ${ }^{8}$ the numbers of nucleolar organiser regions are related to the degree of malignancy of the tumours.

Malignant mesothelioma is an uncommon tumour with variable histological appearances. ${ }^{9}$ The two major areas of difficulty in the pathological diagnosis of this tumour are in its differentiation from adenocar-

Address for reprint requests: Dr J G Ayres, Department of Respiratory Medicine, East Birmingham Hospital, Birmingham B9 5ST.

Accepted 26 January 1988 cinoma and, in pleural biopsy specimens, in defining whether the mesothelial cells are "reactive" or malignant. In an attempt to throw light on the latter $-\times$ problem we have applied the AgNOR technique to 3 . normal pleura and to pleura obtained from patients with "reactive" and malignant pleural disease to determine whether this simple staining method can ${ }_{\circ}$ help to separate benign from malignant disease of the pleura.

\section{Methods}

Blocks of pleural tissue obtained at thoracotomy orN necropsy were studied. Specimens were obtained from ${ }_{\sigma}$ 10 subjects with normal pleura, from 10 subjects with pleura having "reactive" histological changes, and from 25 patients with mesothelioma. In the cases of $\stackrel{\mathbb{Q}}{+}$ "reactive" changes the tissue was obtained at necropsy" in five and at open lung biopsy in five (table). In the open lung biopsy specimens the underlying cause was assessed as inflammatory (that is, resolving pleurisy $\underset{\mathbb{D}}{\mathbb{D}}$ with or without pneumonia) in all cases because of the $\varrho$ findings at thoracotomy and the subsequent recovery 


\begin{tabular}{|c|c|c|c|c|c|c|}
\hline & \multirow[b]{2}{*}{$\begin{array}{l}\text { Normal } \\
(n=10)\end{array}$} & \multirow[b]{2}{*}{$\begin{array}{l}\text { Reactive } \\
(n=10)\end{array}$} & \multicolumn{4}{|l|}{ Mesothelioma } \\
\hline & & & $\begin{array}{l}\text { Tubulopapillary } \\
(n=10)\end{array}$ & $\begin{array}{l}\text { Undifferentiated } \\
(n=5)\end{array}$ & $\begin{array}{l}\text { Sarcomatous } \\
(n=5)\end{array}$ & $\begin{array}{l}\text { Mixed } \\
(n=5)\end{array}$ \\
\hline & $\begin{array}{l}0.9 \\
1.0 \\
1.0 \\
1.0 \\
1.0 \\
1.0 \\
1.0 \\
1.1 \\
1.1 \\
1.3\end{array}$ & $\begin{array}{l}0.9^{*} \\
1 \cdot 0^{*} \\
1 \cdot 3 \\
1 \cdot 5 \\
1 \cdot 7^{*} \\
2 \cdot 1 \\
2 \cdot 2^{*} \\
2 \cdot 2 \\
2 \cdot 3 \\
2 \cdot 4^{*}\end{array}$ & $\begin{array}{l}3 \cdot 9 \\
3.9 \\
4 \cdot 3 \\
4.5 \\
4 \cdot 6 \\
6 \cdot 1 \\
6 \cdot 2 \\
6 \cdot 3 \\
7 \cdot 0 \\
7 \cdot 5\end{array}$ & $\begin{array}{l}3 \cdot 2 \\
4 \cdot 8 \\
4 \cdot 9 \\
5 \cdot 5 \\
6 \cdot 6\end{array}$ & $\begin{array}{r}4 \cdot 1 \\
5 \cdot 7 \\
8.4 \\
8.9 \\
10 \cdot 5\end{array}$ & $\begin{array}{l}3 \cdot 5 \\
4 \cdot 2 \\
4 \cdot 5 \\
6 \cdot 1 \\
6 \cdot 4\end{array}$ \\
\hline $\begin{array}{l}\text { Mean } \\
\text { SD }\end{array}$ & $\begin{array}{l}1.04 \\
0 \cdot 11\end{array}$ & $\begin{array}{l}1.75 \\
0.55\end{array}$ & $\begin{array}{l}5.43 \\
1.34\end{array}$ & $\begin{array}{l}5.00 \\
1.23\end{array}$ & $\begin{array}{l}7.52 \\
2 \cdot 56\end{array}$ & $\begin{array}{l}4.94 \\
1.25\end{array}$ \\
\hline $\begin{array}{l}95 \% \\
\text { CI }\end{array}$ & $0.96-1 \cdot 12$ & $1 \cdot 34-2 \cdot 16$ & $4.42-6.44$ & $3 \cdot 29-6 \cdot 71$ & $3.96-11.08$ & $3 \cdot 2-6 \cdot 68$ \\
\hline
\end{tabular}

*Necropsy specimens.

$\mathrm{CI}-$ confidence interval.

of the patient. In the case of the postmortem specimens all the patients had had pneumonia with pleurisy. In three cases the pneumonia was distal to an obstructing tumour, but there was no histological evidence of tumour in the area from which the biopsy specimen for this study was taken. Normal pleura was obtained from resected lobes or lungs for localised carcinomas with no peripheral extension of tumour. Mesothelioma tissue was obtained by open lung biopsy in each case; the tumour was classified according to the nomenclature used by Whitwell and Rawcliffe. ${ }^{10}$ Of the 25 specimens, 10 were tubulopapillary, five undifferentiated polygonal cell, five sarcomatous, and five mixed type tumours. The nature of the tumours was confirmed by positive alcian blue-hyaluronidase staining and lack of immunohistochemical reaction for carcinoembryonic antigen.

The method for staining nucleolar organiser regions is fully described elsewhere. ${ }^{8}$ Briefly, sections were dewaxed, taken to water, and washed in deionised, distilled water. The reaction mixture consisted of gelatin in $1 \mathrm{~g} / \mathrm{dl}$ formic acid to make a $2 \mathrm{~g} / \mathrm{dl}$ solution, which was then mixed with $50 \mathrm{~g} / \mathrm{dl}$ silver nitrate in a proportion of 1:2. After 30 minutes' incubation at room temperature in the dark the specimens were washed, taken to xylene, and mounted in synthetic

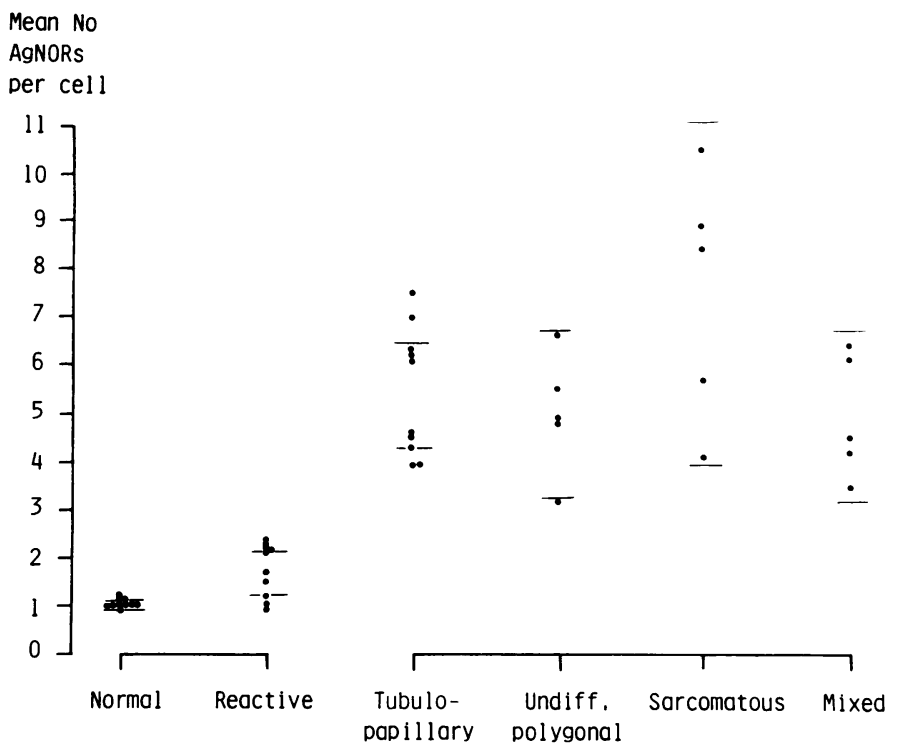

Mesothelioma
Fig 1 Mean number (with $95 \%$ confidence intervals) of stained nucleolar organiser regions (AgNOR dots) per cell for normal pleura, reactive pleura, and the four histological grades of mesothelioma. 


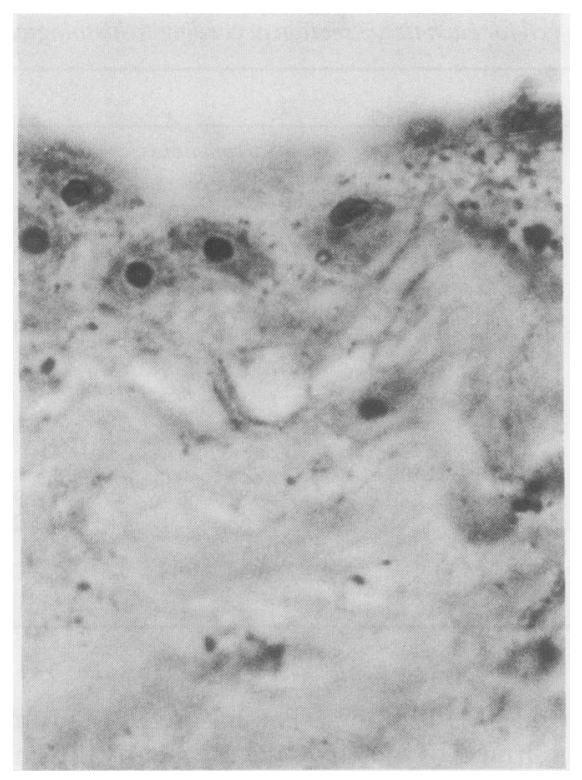

Fig 2 Normal pleura showing on average one stained nucleolar organiser region (AgNOR dot) per cell (focusing confirmed this number).

medium. For each sample the number of silver stained nucleolar organiser regions (AgNORs) in 100 cells were counted with the aid of a graticule, with careful focusing on each cell to enable clear identification of each AgNOR dot. It is impossible to enumerate AgNOR dots without knowledge of the histological type; interobserver variation in our hands is of the order of $10 \%$. Cells and fields were selected at random. In the mixed type of tumour, acinar and spindle cells were counted in proportion to their presence in the biopsy specimen. Inflammatory and stromal cells (such as endothelial cells and fibroblasts) were excluded.

For statistical analysis we used Student's $t$ test for unpaired data and calculation of $95 \%$ confidence intervals (CI).

\section{Results}

The mean number of AgNOR dots per nucleus was $1.04(95 \%$ CI 0.96-1.12) for normal mesothelial cells and 1.75 (1.34-2.16) for "reactive" cells (table and figs $1-3)$. These values were significantly different $(p<$ 0.001 ). The pooled value for normal and reactive specimens was 1.4 (1.14-1.66).

The mean number of AgNOR dots for the mesotheliomas ranged from $4.94(95 \%$ CI $3 \cdot 2-6.68)$ in the mixed type to $7.52(3.96-11.08)$ for the sarcomatous type (table and figs 1,4 , and 5 ). The pooled data for all
25 mesotheliomas, regardless of cell type, was $5.66 \stackrel{\mathscr{N}}{\times}$ (4.92-6.4), which was highly significantly different $\overrightarrow{\vec{F}}$ from the pooled data for normal and reactive data combined $(p<0.001)$.

\section{Discussion}

After the original identification of nucleolar organiser $\approx$ regions by cytogeneticists and their subsequent use of $\overrightarrow{0}$ the regions in the investigation of certain trisomies, ${ }^{11}$. interest has recently turned to the number and dis- $\vec{\omega}$ tribution of nucleolar organiser regions in malignant cells. $^{38}$ After the initial observation that more $\vec{x}$ nucleolar organiser regions were present in prostatic $\vec{\omega}$ carcinoma cells than in cells from a hyperplastic or prostate ${ }^{2}$ similar observations have been made in $\omega_{\sigma}$ lymphoma, ${ }^{8}$ small cell carcinoma of the bronchus, ${ }^{5}$ o

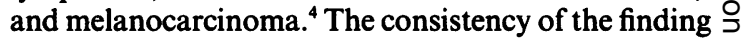
that malignant cells from different organ sites have $\rightarrow$ more nucleolar organiser regions than the cells of their tissue of origin suggests that this simple technique is an indicator of malignancy. It may consequently replace $\vec{\oplus}$ or be complementary to flow cytometry in this regard. $\stackrel{\infty}{\infty}$ Recent modifications (discussed elsewhere ${ }^{8}$ ) have simplified and improved the sensitivity of the AgNOR technique, making it easy to use in any laboratory. The interobserver and intraobserver variation in counting AgNORs is $10-12 \%$.

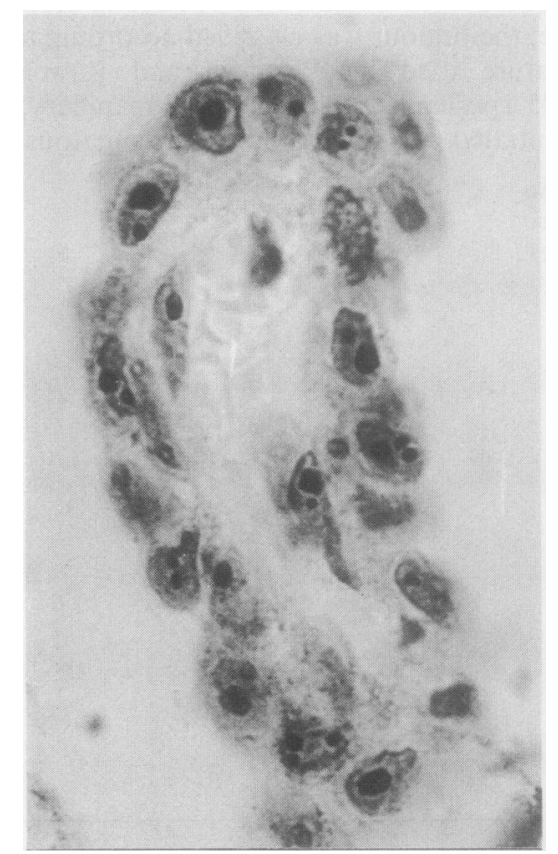

Fig 3 Pleural tissue showing reactive mesothelial cells showing about two stained nucleolar organiser regions (AgNOR dots) per cell nucleus. 


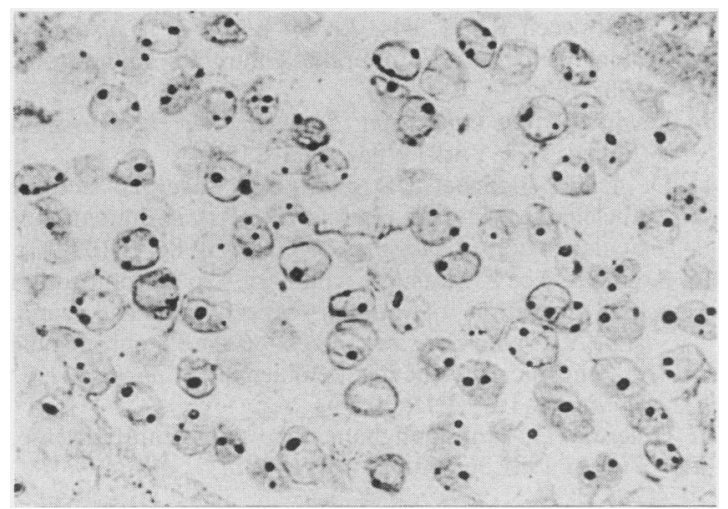

Fig 4 Tubulopapillary type mesothelioma showing increased numbers of stained nucleolar organiser regions (AgNOR dots) per cell.

Our findings show that, in an area which has caused much diagnostic difficulty in the past, the AgNOR technique is able to separate clearly malignant from benign pleura. Previous attempts to do this by the use of antibodies to epithelial membrane antigen have been unsuccessful.12 Other immunohistochemical methods have been applied to the problem of separating adenocarcinoma from mesothelioma, the most useful being staining for carcinoembryonic antigen and $\beta_{1}$ pregnancy specific glycoprotein. ${ }^{13}$ These are both negative in all but a few mesotheliomas, whereas in adenocarcinoma one or both are invariably positive. ${ }^{13}$ These techniques do not, however, differentiate between reactive and malignant mesothelial cells

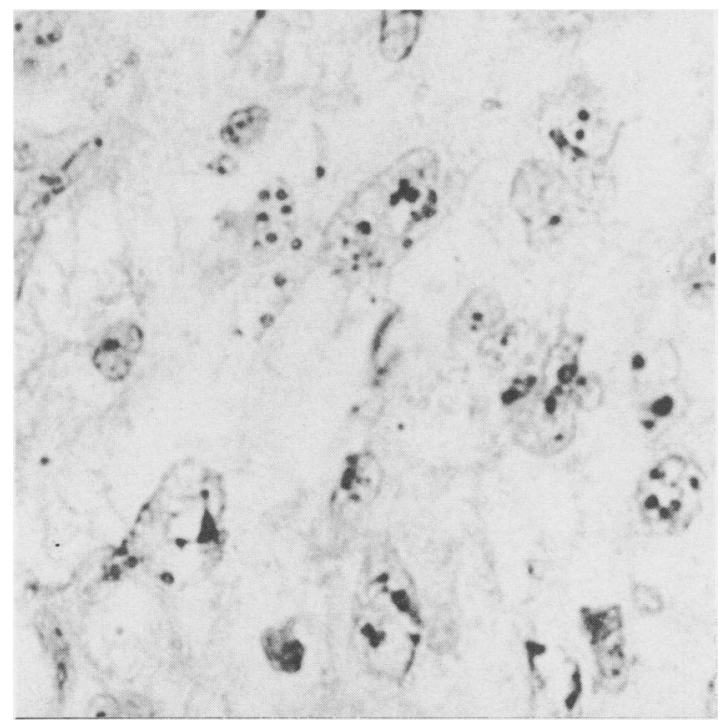

Fig 5 Sarcomatous mesothelioma averaging eight stained nucleolar organiser regions (AgNOR dots) per cell. in a consistent manner. Our findings confirm that the cells from all four types of mesothelioma have more AgNORs than cells from either normal or "reactive" pleura, the largest number being in the sarcomatous form. We must emphasise that the sections used in this study were cut at $3 \mu \mathrm{m}$ thickness, and the quoted numbers of AgNOR dots thus are not absolute numbers of nucleolar organiser regions per nucleus, which can be obtained only from cell imprint preparations. ${ }^{8}$ The configuration and distribution of the AgNORs (found only on chromosomes 13, 14, 15, 21 , and 22 in normal human cells ${ }^{14}$ ) have yet to be investigated fully in malignant cells, although "ectopic" AgNORs have been reported in metaphase spreads of testicular cancer and myeloid leukaemia cells. $^{1516}$

The finding that "reactive" cells can be separated from normal cells by this technique shows for the first time that this method may be extended to the investigation of inflammatory diseases. Further investigation here should look at possible differences between the nucleolar organiser regions of inflammatory lesions and those of low grade malignancy.

The prognosis of mesothelioma is very poor, most patients dying within two years of presentation. It is important when a patient with a pleural effusion has been exposed to asbestos to obtain a firm diagnosis. The benign pleural effusion associated with asbestos exposure carries a far better prognosis, ${ }^{17}$ although there is some suggestion that the condition might be premalignant. Assessment of mesothelial cells from such patients with the AgNOR technique would be of interest, diagnostically in the first instance, and over a long period with serial measurements that might help to detect the development of malignant change.

\section{References}

1 Alberts B, Bray J, Lewis J, Raff M, Roberts K, Watson JD. Molecular biology of the cell. New York: Garland, 1983:424-6.

2 Ploton D, Menager M, Jeannesson P, Himber G, Pigeon F, Adnett JJ. Improvement in the staining and in the visualisation of the argyrophilic proteins of the nucleolar organizer region at the optical level. Histochem J 1986;18:5-14.

3 Editorial. NORs-a new method for the pathologist. Lancet 1987; i:1413-4.

4 Crocker J, Skilbeck NQ. Nucleolar organiser regionassociated proteins in cutaneous melanotic lesions: a quantitative study. J Clin Pathol 1987;40:885-9.

5 Crocker J, Ayres J, McGovern J. Nucleolar organiser regions in small cell carcinoma of the bronchus. Thorax 1987;42:972-5.

6 Smith R, Crocker J. Evaluation of nucleolar organizer region-associated proteins in breast malignancy. Histopathology 1988;12:113-25.

7 Ochs RL, Buswch H. Further evidence that phospho- 
protein $\mathrm{C}_{23}(110 \mathrm{KD} / \mathrm{pH} 5 \cdot 1)$ is a nucleolar silver staining protein. Exp Cell Res 1984;152:260-5.

8 Crocker J, Nar P. Nucleolar organizer regions in lymphomas. J Pathol 1987;151:111-8.

9 Spencer H. Pathology of the lung. 4th ed. Oxford: Pergamon Press, 1984:1006-10.

10 Whitwell F, Rawcliffe RM. Diffuse malignant pleural mesothelioma and asbestos exposure. Thorax 1971;26:6-22.

11 de la Cruz FF, Gerald PS. Trisomy 21. Baltimore: University Park Press, 1981:165-7.

12 Kerr KM, Cossar D, Krajewski AS, Lamb D. Histochemistry in the diagnosis of pleural biopsies [abstract]. Thorax 1987;42:211.

13 Gibbs AR. Industrial lung disease. In: Anthony PP,
Macsween RNM, eds. Recent advances in histopath- ? ology. No 13. Edinburgh: Churchill Livingstone, 1987:109-28.

14 Lewin B. Gene expression: 2. Eukaryotic chromosomes. 2nd ed. New York: Wiley, 1980:875-8.

15 De Lazier-Blanchet CD, Walt H, Engel E. Ectopic nucleolus organizer regions (NORs) in human tes- $\mathbb{D}$ ticular regions. Cytogenet Cell Genet 1986;41:107-13.

16 Kohno S, Abe S, Matsui S, Sandberg AA. Chromosomes $s$ and causation of human cancer and leukaemia. $\vec{O}$ XXXVII. Nucleolus organizers on the Ph chromsome in chronic myelocytic leukaemia. Cancer Genet Cytogenet 1979;1:15-20.

17 Hillerdal G. Non-malignant asbestos pleural disease. Thorax 1981;36:669-75. 